\title{
Growth at the microscale: long term thinning effects on patterns and timing of intra-annual stem increment in radiata pine

David M. Drew ${ }^{1 *}$ and Geoffrey M. Downes ${ }^{2}$

\begin{abstract}
Background: Stem radial growth in forests is not uniform. Rather, it is characterized by periods of relatively fast or slow growth, or sometimes no growth at all. These fluctuations are generally a function of varying environmental conditions (e.g. water availability) and, importantly, will also be associated with adjustments in properties in the wood formed. Stand level conditions and forest management, particularly thinning and stand density will, however, also have a major influence on patterns of growth variation. We explore how different thinning histories and/or stand densities influence these dynamics of tree growth in the important commercial plantation species Pinus radiata D. Don.
\end{abstract}

Methods: Daily stem size change was measured using electronic point dendrometers over two growing seasons on $P$. radiata trees at two sites, subjected to different thinning regimes. Timing, rates and periodicity of annual growth were calculated from these data.

Results: Greater overall cross-sectional growth in thinned plots was driven mainly by two dynamics. First, the cessation of seasonal growth occurred at least 3 weeks later in the stands in which thinning had taken place. There was no difference between thinned/unthinned stands, however, in the timing of growth onset. Second, within the longer season, trees in thinned plots had more growth days (as much as $20 \%$ more) than unthinned plots. The rates of growth on days when growth occurred were not different, however. In this context, it is notable that in trees in the unthinned plots experiencing the most severe competition there were strong "pulses" of growth following drought-breaking rainfall events. Unthinned plots at high stand densities also maintained a smaller (but consistent) zone of dividing cells throughout the season than thinned plots.

Conclusions: In Pinus radiata growing under conditions as in our study, conditions late in summer, particularly drought, have an important effect on the timing of cessation of growth. Early season temperature appears to have no effect in determining timing of annual growth. Limiting conditions during the season reduce growing duration, and thus total growth, more in unthinned stands than thinned stands. These findings are valuable in developing new generations of fine-scale growth and wood property models.

Keywords: Monterey pine, Dendrometer, Intra-annual growth, Drought, Thinning

\footnotetext{
*Correspondence: drew@sun.ac.za

'Department of Forest and Wood Science, Stellenbosch University, Private

Bag X1, Matieland 7800, South Africa

Full list of author information is available at the end of the article
} 


\section{Background}

Growth and productivity in managed forests is typically considered in terms of total increment over the length of a commercial rotation, and the pattern of increasing yield is frequently modelled by some kind of monotonically increasing function (Burkhart and Tomé 2012). Approaches to modelling and predicting tree or forest growth seldom, if at all, consider variability within rotations, including in intensively managed plantation forests. However, the accumulation of tree growth over these periods is not uniform. Rather, it is characterized by some periods of no growth, or periods of relatively faster and slower growth. This is definitely true of plantation species like Pinus radiata D. Don growing in the Australian environment (Downes et al. 2009; Drew et al. 2009), which is the focus of the study reported here. Pinus radiata (or radiata pine) is by far the largest softwood plantation species in Australia (Downham and Gavran 2017). Typically grown for a minimum of about 20 years, although sometimes for as long as 30-40 years (Leech 2014), P. radiata in Australia is intensively and carefully managed for a range of products whose properties and the yield of which need to be as predictable as possible. To that end, understanding growth periodicity and short-term variability is undoubtedly of importance, both in predicting growth with the greatest accuracy, but also to understand resultant wood property variability (Downes and Drew 2008; Drew et al. 2011). In order to develop a finer and more precise understanding of growth at this level, it is of great value to understand better the periodicity and temporal variability of growth in forest trees (Rossi and Deslauriers 2007; Drew and Downes 2015; Bosio et al. 2016; Brinkmann et al. 2016). The measurement of fine-scale variation in stem size, and ultimately short-term variation in growth, provides a wealth of insightful data. The application of high-resolution dendrometer measurements to softwoods, which has been more widely applied in northern forests (see, for example, Zweifel et al. 2006; Deslauriers et al. 2007), yields data useful for elucidating variability in and factors driving growth rates at different times of the year (Rossi et al. 2006b; Bosio et al. 2016). Fine-scale variability, and the drivers of short-term growth responses is still poorly understood, however, particularly in $P$. radiata. While some work has been done in this area on fast growing plantations of other species in countries like Australia and South Africa (Downes et al. 1999; Drew et al. 2008; Zweifel et al. 2014) and a relatively large literature exists for northern hemisphere forests (e.g. Deslauriers et al. 2007; Steppe et al. 2015) only a small amount of older work (e.g. Worrall 1966; Skene 1969) has been published for $P$. radiata to our knowledge.

In this context, another important factor to consider in managed forests is the effect of stand density (SD) and thinning. It is well known that thinning will lead to increased basal area increment (Burkhart and Tomé 2012) and that adjustments in stand density will have effects on wood properties (e.g. wood density), although these effects are variable (Drew et al. 2017). Given the very critical forest management variable of stand density, either at planting, or through thinning, a question then arises: Will growth responses and intra-annual growth dynamics differ in trees growing at higher compared to those growing under lower stand densities?

Our main objective in this study was to explore if/how differences in thinning histories and "current" stand density led to changes in the timing and dynamics of intra-annual growth in Pinus radiata. Based on work done in $P$. radiata as well as other species, we expected that higher basal area growth in plots following thinning would be attributable to a combination of (i) increased duration of growth, (ii) frequency of days of growth and (iii) higher short-term growth rates during the seasons (cf. Olivar et al. 2014). We also expected that environmental conditions in (i) late winter/early spring and (ii) late summer would have an important effect on onset and cessation (respectively) of the main season of annual growth.

\section{Methods}

\section{Study sites}

Two Australian sites, planted with Pinus radiata, were used for this study (Table 1). The Flynn site is in the East Gippsland region of the State of Victoria, managed by Hancocks Victoria Plantations (HVP) and the Mt. Gambier site, managed by Forestry South Australia (ForestrySA) (now renamed) in the Green Triangle region of South Australia (Table 1). In both cases, thinning treatments had been applied prior to the onset of our dendrometer measurements (Table 2). Average temperature and rainfall for the two sites are given in Table 3. Both sites are sandy, with similar annual average temperature

Table 1 General information about the two sites intensively monitored in this study, with the start and end years of the data range

\begin{tabular}{|c|c|c|c|c|c|c|}
\hline Site Name & $\begin{array}{l}\text { Latitude } \\
\text { (deg S) }\end{array}$ & $\begin{array}{l}\text { Longitude } \\
\text { (deg E) }\end{array}$ & $\begin{array}{l}\text { Elevation } \\
\text { (m AMSL) }\end{array}$ & $\begin{array}{l}\text { Dendrometers } \\
\text { monitored over years }\end{array}$ & Plant year & Soil type \\
\hline Flynn & -38.26 & 146.68 & 150 & $2011-2013$ & June 1995 & Sand overlying clay \\
\hline Mt Gambier & -37.74 & 140.78 & 57 & 2010-2012 & February 1995 & Deep sands \\
\hline
\end{tabular}


Table 2 treatments applied and initial planting densities at the study sites. T1 and T2 refer to the first and second thinnings respectively

\begin{tabular}{|c|c|c|c|c|}
\hline Site & Treatment & $\begin{array}{l}\text { Establishment stand density } \\
\left(\text { stems } h \mathrm{ha}^{-1}\right)\end{array}$ & $\begin{array}{l}\text { Establishment spacing } \\
\text { ( } \mathrm{m} \text { between trees) }\end{array}$ & Thinning \\
\hline \multirow[t]{3}{*}{ Mt Gambier } & Thinned twise & 2222 & $2.5 \times 1.8$ & $\begin{array}{l}\text { T1 to } 1111 \text { in } 2000 ; \text { T2 to } 555 \\
\text { stems.ha }{ }^{-1} \text { in } 2007\end{array}$ \\
\hline & Thinned once & 1111 stems.ha ${ }^{-1}$ & $2.5 \times 3.6$ & $\begin{array}{l}\text { T1, thin to } 555 \text { stems } \cdot \mathrm{ha}^{-1} \\
\text { in } 2001\end{array}$ \\
\hline & E3 & 556 & $5.0 \times 3.6$ & None \\
\hline \multirow[t]{2}{*}{ Flynn } & Thinned & $1111(2.5 \times 3.6)$ & $2.5 \times 3.6$ & None \\
\hline & Unthinned & $1111(2.5 \times 3.6)$ & $2.5 \times 3.6$ & T1 to 200 stems.ha ${ }^{-1}$ in 2008 \\
\hline
\end{tabular}

and rainfall, but Flynn, received more rainfall than Mt. Gambier during our study.

\section{Dendrometers and monitoring growth}

High resolution point dendrometers were used to monitor stem growth at 15 min sampling intervals on three trees per plot, mounted at $1.3 \mathrm{~m}$ above ground level. Data were finally averaged to a daily time step. The Mt. Gambier site was instrumented in Oct 2010, and in Oct 2011 instruments were installed at Flynn (HVP). Growth was monitored for two seasons in each case, although started a year apart due to practical issues which delayed the Flynn installation.

Different, but comparable, systems were used at two sites. The dendrometers at Mt. Gambier used custom-designed housings and mountings, with the sensor itself a Macrosensors AC LVDT (http://www.te.com). Sensors were connected to a Campbell Scientific (http:// www.campbellsci.com) CR1000 data loggers via a multiplexor and Macrosensors signal conditioner. The systems at Flynn used dendrometers incorporating Midori Precisions "GreenPot" radial potentiometers (http:// www.midori.co.jp) connected to a Campbell Scientific CR800 data logger. Every dendrometer was individually calibrated in the laboratory prior to installation in the field, and temperature sensitivity provided by the suppliers taken into account in the data logger program. Data were regularly uploaded into a MySQL database, where they were stored and processed further.

\section{Weather data}

Daily maximum and minimum temperatures, total daily rainfall and total evapotranspiration were obtained for the two study sites from the SILO interpolated data grid (Beesley et al. 2009). This facility uses actual weather data for each date from the nearest weather station/s and provides the best possible estimate of conditions at the particular site by taking into account effect topography and proximity. The approach relied on thin plate smoothing splines for interpolating daily climate variables except daily and monthly rainfall, for which ordinary kriging was used (Jeffrey et al. 2001).

\section{Cambial sampling and analyses}

Cambial micro-core samples were taken from the three trees per plot on which dendrometers were mounted the Flynn site on four separate occasions during the 2011-2012 growing season using a Trephor corer (Rossi et al. 2006a). These samples were immediately placed in FAA fixative solution (35\% distilled water $/ 50 \%$ ethyl alcohol $/ 5 \%$ glacial acetic acid/10\% formaldehyde). Samples were later reduced in size, mounted in resin, and sectioned to a thickness of $4 \mu \mathrm{m}$. These sections were mounted on glass slides, and images captured using a Zeiss Axioscope microscope (Zeiss, Oberkochen, Germany). The numbers of cells in the dividing (cambial) zone and subsequent stage of permanent enlargement were counted, based on increasing radial diameter and the onset of secondary thickening (determined by detecting birefringence in the cell wall) which was taken to indicate the end of enlargement.

\section{Data analysis}

Data management and analysis in this study was undertaken using a MySQL database and the $\mathrm{R}$ system for Statistical computing ( $\mathrm{R}$ Core Team 2016). When there were temporary issues resulting from dendrometer failure, generally of short duration, a spline-based interpolation was used to fill in gaps for the purposes of calculating rates of change and other variables.

Table 3 Mean maximum and minimum temperatures and rainfall, received at the four study sites over the two year period from mid September 2010 to mid September 2012 and long term annual rainfall

\begin{tabular}{lllll}
\hline Site & $\begin{array}{l}\text { Mean min. Annual } \\
\text { temperature }\left({ }^{\circ} \mathrm{C}\right)\end{array}$ & $\begin{array}{l}\text { Mean max. Annual } \\
\text { temperature }\left({ }^{\circ} \mathrm{C}\right)\end{array}$ & $\begin{array}{l}\text { Total rainfall } \\
(2 \text { years })(\mathrm{mm})\end{array}$ & $\begin{array}{l}\text { Long term rainfall } \\
\text { average }(\mathrm{mm})\end{array}$ \\
\hline Mt Gambier & 8.9 & 19.4 & 1600 & 710 \\
Flynn & 8.5 & 19.0 & 2000 & 780 \\
\hline
\end{tabular}



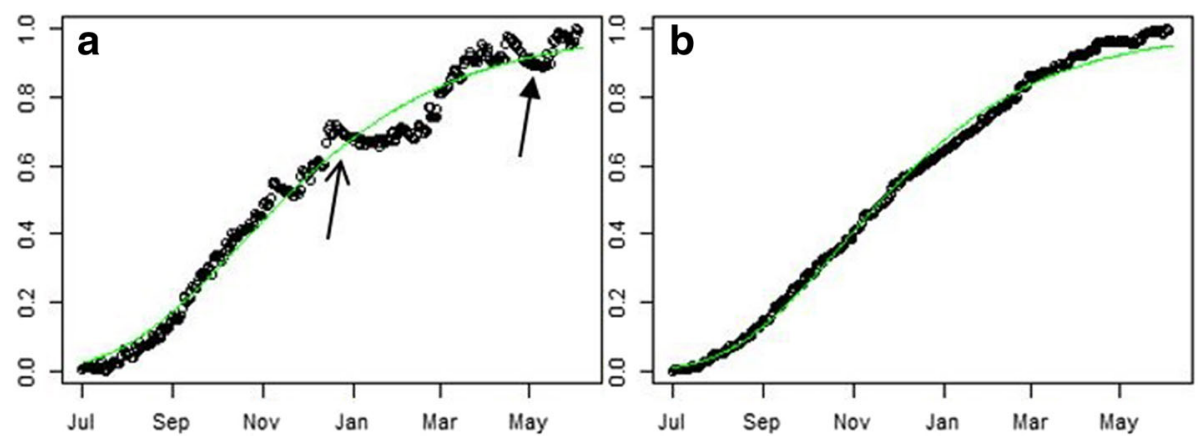

Fig. 1 Examples of a year's growth for two trees to which Gompertz curves were fitted. A slower growing tree, in which a marked temporary growth slow-down occurred is shown in (a) while a faster growing tree which showed more constant growth is shown in (b). The open arrow shows where growth cessation may have been erroneously allocated if a smoothing function had not been used. The solid arrow shows where growth cessation was actually taken to have occurred after smoothing using the Gompertz function

The onset and cessation of growth was determined not on the raw data, but on modelled annual growth data from a fitted Gompertz function to ensure the initial and final change points of the "main" annual growth trajectory were being captured (see, for example, van der Maaten 2013). The fit of the Gompertz equation against relative stem size increase in two very different trees is shown in Fig. 1. The Gompertz equation fitted the data well at the tree-level. Onset of growth was defined to be the point at which stem diameter exceed $2.5 \%$ of the minimum size for the season and cessation the point at which the stem reached $97.5 \%$ of the maximum diameter. The number of days of growth was defined to be all days within a monitored period on which a net increment (as opposed to zero change or a shrinkage) could be detected. The sum of these days divided by the total days monitored yielded an estimate of the growth proportion.

Growth proportion or days, onset and cessation of growth, average growth rates were tested between sites, treatments at sites and between years simply using a Student's t test, in cases where there was a contrast between two cases (e.g. Flynn treatments), and in cases with more than one contrast (e.g. Mt. Gambier treatments), assessment of differences was done using analysis of variance, followed by a pairwise comparison of means using the Tukey HSD test.

\section{Results}

\section{Initial tree sizes}

The stand density at the Flynn site in the plot which had never been thinned (planted at 1111 stems.ha ${ }^{-1}$ ) had experienced some self-thinning by the time the study reported here began, with stand densities already at about 975 stems.ha ${ }^{-1}$ ). In the plots, at both sites, where a thinning of any sort had been undertaken, there was no indication that there had been mortality after thinning, and stand densities were essentially at the level to which the stands had been thinned. At Flynn, trees in the thinned plots were significantly $(p<0.001)$ larger than the unthinned plots. At Mt. Gambier, only the trees that had initially been planted at 2222 stems $\cdot \mathrm{ha}^{-1}$, and then thinned twice, were significantly $(p<0.001)$ smaller than the other two treatments. The trees that had been planted at 555 stems $\cdot \mathrm{ha}^{-1}$ (and unthinned) were not different $(p=0.120)$ in diameter (DBH) compared to trees planted at 1111 stems.ha ${ }^{-1}$ and then thinned once (Table 4).

Table 4 Initial mean diameters and residual stand densities of trees in the study plots

\begin{tabular}{llll}
\hline Site & Treatment & $\begin{array}{l}\text { Mean DBH } \pm 1 \\
\text { standard error (cm) }\end{array}$ & $\begin{array}{l}\text { Stand density at the time of } \\
\text { dendrometer installation } \\
\left(\text { stems.ha }{ }^{-1}\right)\end{array}$ \\
\hline Flynn & Thinned & $29.8 \pm 0.05$ & 976 \\
& Unthinned & $22.4 \pm 1.00$ & 200 \\
Mt Gambier & Thinned twice & $26.9 \pm 0.86$ & 550 \\
& Thinned once & $35.0 \pm 1.39$ & 549 \\
& Unthinned & $32.5 \pm 1.87$ & 551 \\
\hline
\end{tabular}




\section{Weather conditions and patterns of growth during our study}

Patterns of daily growth and overall increase in stem size over the periods for which dendrometers were installed at the study sites is shown in Fig. 2 and Fig. 3. The graphs illustrate the increase in stem radius relative to a zero start point, to make visual assessment of patterns easier, as well as the daily growth rate in stem basal area $\left(\mathrm{mm}^{2} \cdot \mathrm{d}^{-1}\right)$. At both sites, but particularly at Mt. Gambier, there was a growth lull in the winter period from about May to July/August, although some growth was evident throughout the year. At Mt. Gambier, the highest growth rates were seen just after onset, in early Spring, with a general trend of decreasing growth rate thereafter. This pattern was not as evident at Flynn, although there was some indication that growth rates were highest later in the Spring, and declined somewhat thereafter.

At both sites, winter and early spring (when growth started) was slightly cooler in 2012 compared to 2011 (Fig. 4). At both sites, rainfall was lower in February 2012 compared to 2011, and markedly so at Mt. Gambier. At Flynn, Rainfall was lower in late summer months (Jan - April) in 2013 compared to 2012. At the same time, estimated evapotranspiration in late summer was higher in 2012 compared to 2011 and (at Flynn only) in 2013 compared to 2012 (Fig. 4). Taken in concert with the rainfall, mid-summer in 2012 can be considered to have been particularly dry compared to 2011, and 2013 was even drier than 2012 (at Flynn).

\section{Onset, cessation and duration of growth}

Growth started surprisingly early at both sites, and in all treatments: generally no later than late July, and sometimes as early as June. This was despite the relatively cool minimum temperatures at that time of year (Fig. 4). At Mt. Gambier, the only site at which the data allowed a year-on-year comparison, there was no discernable difference between the timing of onset between the years, despite the slightly cooler conditions in 2012 (Table 5). At Flynn, there was evidence that the cessation of growth occurred about 23 days later $(p=0.030)$ in 2012 (relatively wetter) growing season compared to the 2013 (drier). Similarly, at Mt. Gambier (although in this case, comparing between 2011 and 2012), growth ceased

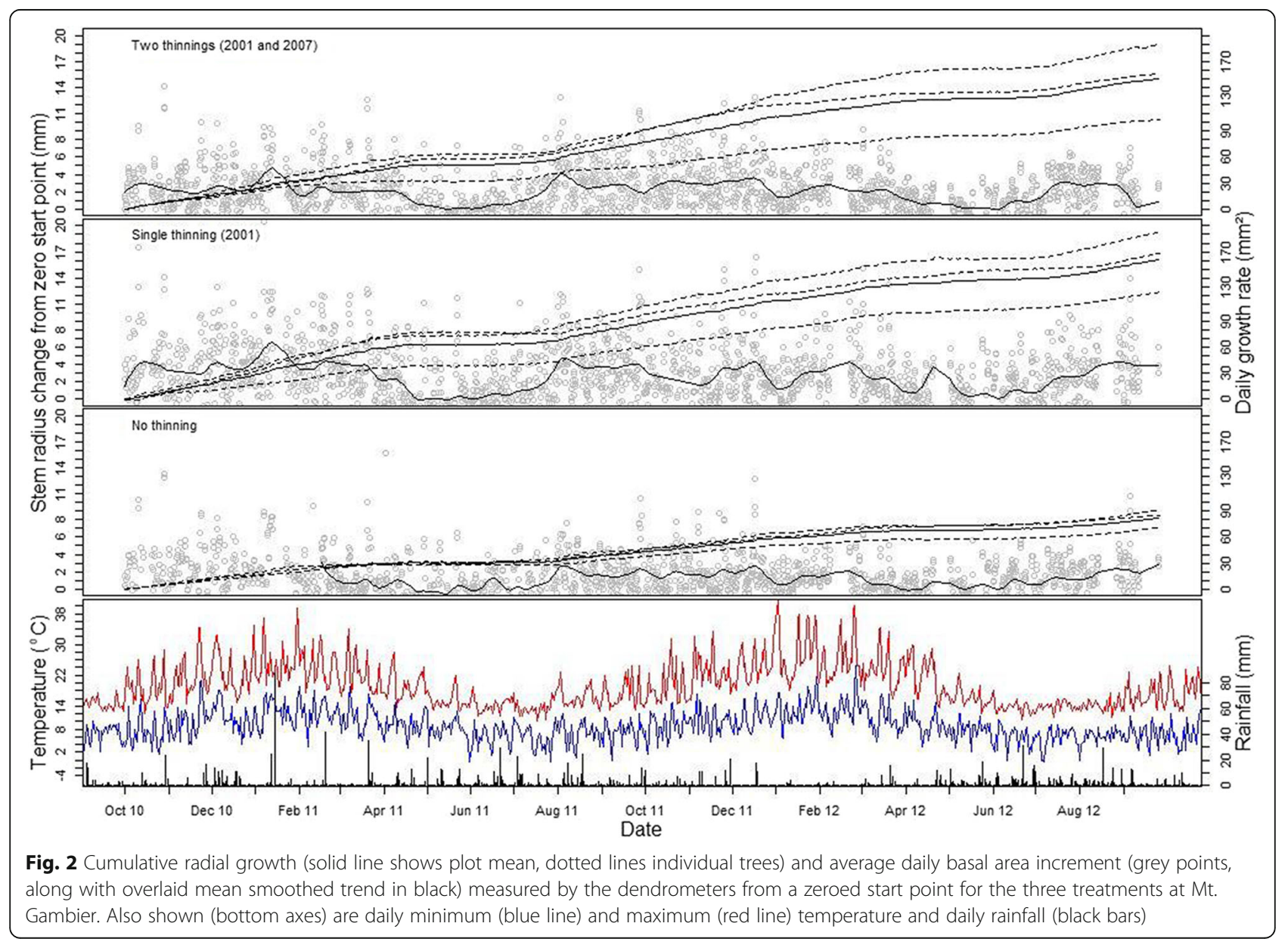




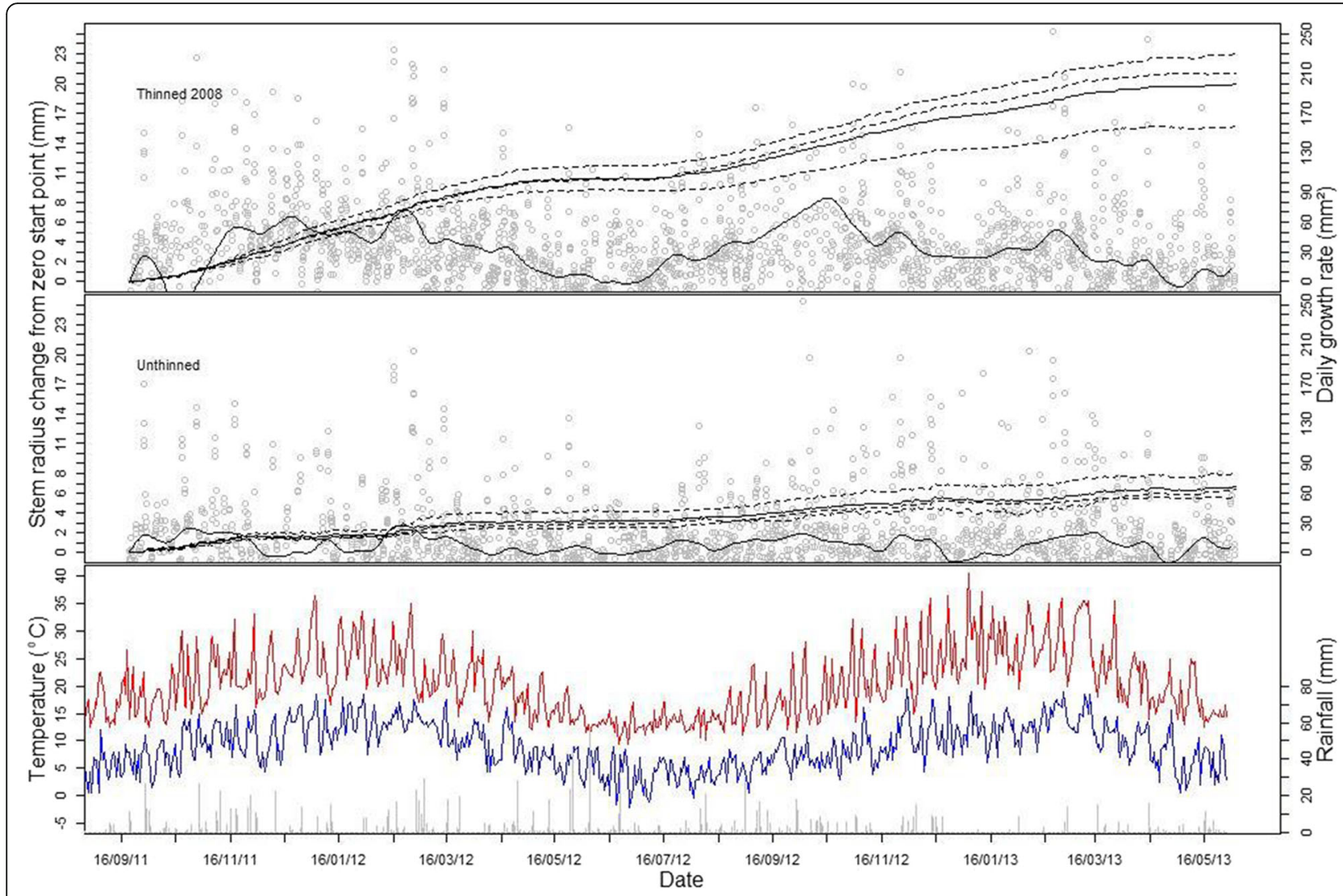

Fig. 3 Cumulative radial growth (solid line shows plot mean, dotted lines individual trees) and average daily basal area increment (grey points, along with overlaid mean smoothed trend in black) measured by the dendrometers from a zeroed start point for the two treatments at Flynn. Also shown (bottom axes) are daily minimum (blue line) and maximum (red line) temperature and daily rainfall (black bars)

about 15 days earlier $(p=0.030)$ in the dry summer of 2012 compared the wetter summer of 2011 (Table 5).

At both sites, there was evidence that the different thinning histories and final spacing had an effect on the timing of the cessation of annual growth but not the onset (Table 5). At Flynn, trees in the thinned plots stopped growing, on average, 26 days later $(p=0.013)$ than the unthinned plots. The overall duration of growth, however, did not differ ( $p=$ 0.147), partly because of higher variability in the timing of the onset of growth. At Mt. Gambier, the trees in the never-thinned treatment stopped growing about 22 days earlier $(p=0.070)$ than the other two treatments and had a significantly shorter growing season duration (241 d vs $293 \mathrm{~d} ; p=0.010$ ).

\section{Growth rates in our study}

Overall, trees in the thinned plots at the Flynn site grew at a rate about $24 \mathrm{~mm}^{2}$ more per day $(p=0.018)$, faster than in the unthinned plots (Table 6). At Mt. Gambier, the unthinned treatment (E3) grew at about half the rate (11 vs $22 \mathrm{~mm}^{2}$ per day; $p=0.020$ ) of the average of the other two treatments, which were not different $(p=0.500)$ from each other.
At Flynn, trees in the thinned plots exhibited positive growth on 174 more days $(p=0.002)$ (out of 623 monitored) than in the unthinned plots. Overall, the unthinned treatment at Mt. Gambier grew for about 60 fewer $(p=0.013)$ days ( $8 \%$ of the total monitored period of $727 \mathrm{~d}$ ) on average than the other two treatments at that site.

If only days on which growth occurred were considered, however (at both Flynn and Mt. Gambier), the differences in growth rate were not significant (Table 6). There was no evidence of any difference in the growth rates of thinned and unthinned plots on days when positive growth was recorded between thinning treatments at Flynn $(p=0.253)$. At Mt. Gambier, there was slight evidence $(p=0.080)$ of slower rates of average daily growth, even on "growth days", in the unthinned treatment compared to the other two treatments combined.

\section{Short-term responses to rainfall events}

The differences between short-term patterns and trends in growth were particularly marked between the thinned and unthinned treatments at the Flynn site. These effects are highlighted over one notable period, as seen in Fig. 5. 

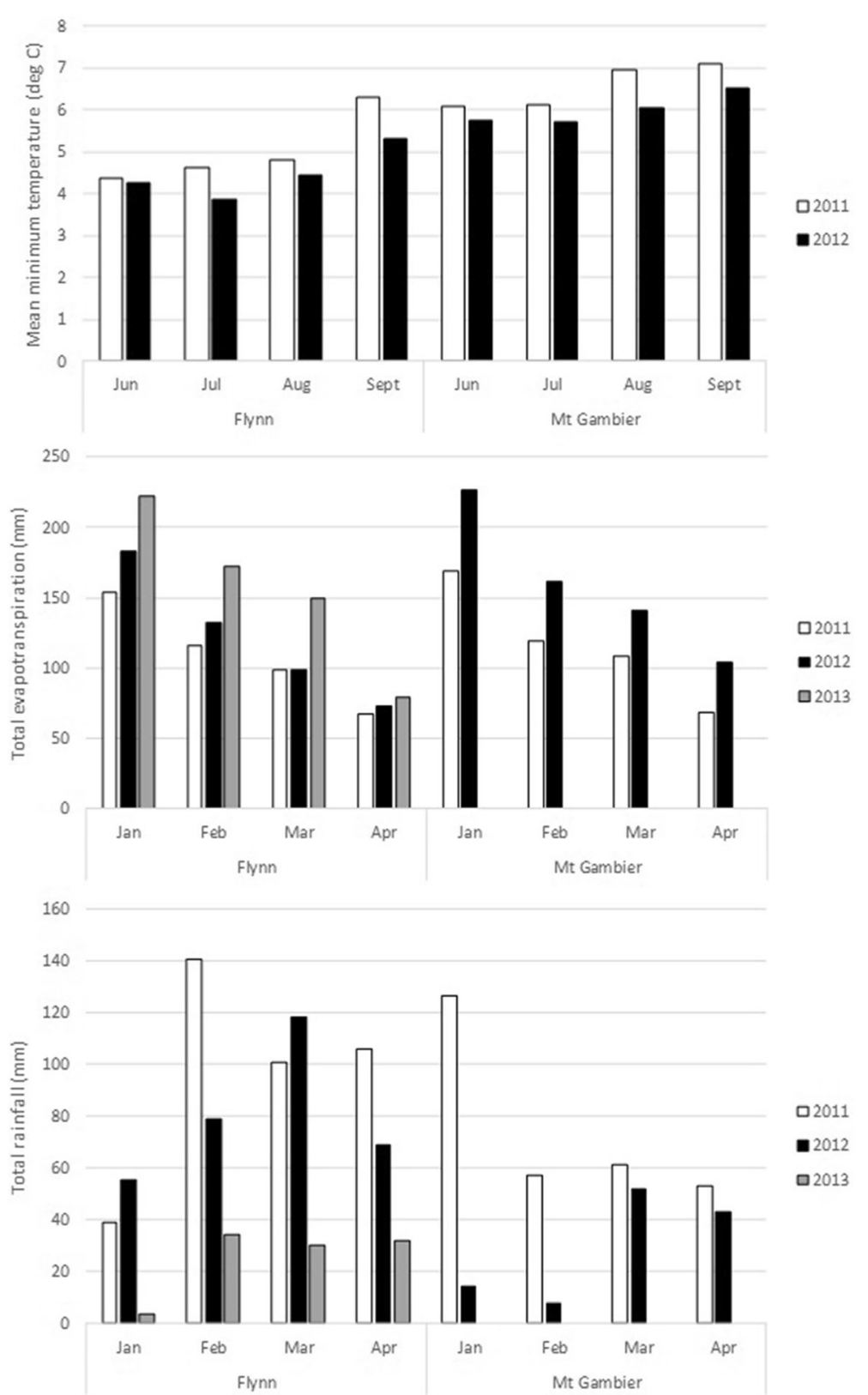

Fig. 4 Monthly minimum temperature during the winter/spring, total monthly rainfall and total monthly evapotranspiration in the summer/ autumn of 2011, 2012 and 2013 for Mt. Gambier and Flynn. Evapotranspiration and rainfall in the late summer in 2013 is only shown for Flynn as growth was no longer being monitored at Mt. Gambier at that time

Prior to the rainfall accumulated between mid and late February 2012, trees in the unthinned plots showed no overall growth from early January. Trees in the thinned plots, on the other hand, were growing actively over the same period. Note the very strong increment which was evident following rainfall events on 17th February, 27th - 28th February and 16th - 17th March. In the unthinned plots, these increments were followed by a period of lower rates of growth, even periods of shrinkage. The average magnitude of the daily shrinkage/ expansion was significantly $(p<0.001)$ smaller in the unthinned plots than the thinned plots.

\section{Cambial dynamics at Flynn}

Over the course of the 2011-2012 growing season, trees in the thinned treatment had significantly $(p<$ $0.001)$ more dividing cells (in the cambial zone) (14.9 \pm 1.3 vs $7.0 \pm 0.5)$ as well as enlarging cells $(13.7 \pm 0.9$ vs $5.4 \pm 0.5$ ) (Fig. 6) compared to the unthinned plots. The ratio of cambial cells to enlarging cells was, 
Table 5 Estimated date of onset and cessation, as well as the duration ( \pm one standard error) of growth at the four study sites in years 2010-2012. Note that an onset/cessation could only be determined for the various sites in in certain years, depending on when the dendrometers were installed

\begin{tabular}{|c|c|c|c|c|c|}
\hline Site & Treatment & $\begin{array}{l}\text { Year on which annual } \\
\text { growth started }\end{array}$ & Onset date & Cessation date & Duration $(\mathrm{d})$ \\
\hline \multirow[t]{4}{*}{ Flynn } & Thinned & 2011 & & 13-May & \\
\hline & & 2012 & 19-Jul & 16-Apr & $271 \pm 8.5$ \\
\hline & Unthinned & 2011 & & 12-Apr & \\
\hline & & 2012 & 17-Jul & 26-Mar & $252 \pm 3.4$ \\
\hline \multirow[t]{9}{*}{ Mt Gambier } & Never thinned & 2010 & & 16-Apr & \\
\hline & & 2011 & 21-Jun & 15-Apr & $297 \pm 6.7$ \\
\hline & & 2012 & 21-Jun & & \\
\hline & Thinned once & 2010 & & 19-Apr & \\
\hline & & 2011 & 05-Jul & 21-Apr & $290 \pm 9$ \\
\hline & & 2012 & 15-Jul & & \\
\hline & Thinned twice & 2010 & & 05-Apr & \\
\hline & & 2011 & 19-Jul & 17-Mar & $241 \pm 11.1$ \\
\hline & & 2012 & 23-Jun & & \\
\hline
\end{tabular}

however, larger in the unthinned plots $(p=0.026)$ (Table 7). There was no evidence of any difference, overall, in the number of cambial and enlarging cells between September, November, December and February sampling ( $p>0.35$ in all pairwise comparisons between months). There was, however, a significant ( $p=$ $0.030)$ declining trend overall from early to late in the growing season which was not the case in the thinned plots. Even in February, there was evidence of high levels of activity in the cambial zone, with a large number of newly formed cell walls clearly discernable and a wide zone of cambial cells (Fig. 6). This could not be detected in the unthinned plots.

\section{Discussion}

We have reported here on intra-annual growth patterns in Pinus radiata, a plantation species of important in several countries (Lavery and Mead 1998; Ivković et al. 2016). We focused on responses as observed at two case study sites at which different thinning treatments had been applied. The silvicultural histories at the two sites were very different, and also quite unusual. At Flynn, a heavy thinning was undertaken only once, and the patterns of growth seen in the remaining trees contrasted with the extreme case of no thinning at all. At Mt. Gambier, the contrast was different: in the study reported here we were studying trees which had "arrived" at the same stand density (556 stems.ha ${ }^{-1}$ ) via three very different silvicultural "pathways". While the level of these effects is quite coarse (a stand level effect, which occurred in all cases some time prior to our fine-scale monitoring), our interest was in the fine-scale effects which could be seen on average in plots which had experienced/were currently experiencing different stand-level competition. It was not our goal to explore tree-level effects.

Unsurprisingly, we found at the Flynn site that trees in the previously heavily thinned stand were significantly larger than those which had not been thinned. On the other hand, at Mt. Gambier, where trees had all been thinned to a similar stand density, only those trees that had been thinned from a very high stand density (2222

Table 6 The overall rates of growth, and rates of growth on days when growth occurred, for the various treatments at each site

\begin{tabular}{lllll}
\hline Site & $\begin{array}{l}\text { Thinning } \\
\text { treatment }\end{array}$ & $\begin{array}{l}\text { Mean overall growth } \\
\text { rate }\left(\mathrm{mm}^{2} \cdot \mathrm{day}^{-1}\right)\end{array}$ & $\begin{array}{l}\text { Mean growth rate on "growth } \\
\text { days" }\left(\mathrm{mm}^{2} \cdot \mathrm{day}^{-1}\right)\end{array}$ & $\begin{array}{l}\text { Ratio of GD growth: } \\
\text { Overall growth }\end{array}$ \\
\hline Flynn & Thinned & $32 \pm 3.62$ & $45.2 \pm 5.61$ & 1.4 \\
& Unthinned & $8 \pm 0.09$ & $34.2 \pm 5.99$ & 4.3 \\
Mt Gambier & Thinned twice & $19.3 \pm 4.36$ & $26.8 \pm 2.74$ & 1.4 \\
& Thinned once & $26 \pm 4.7$ & $37.5 \pm 5.55$ & 1.4 \\
& Never thinned & $11.9 \pm 0.91$ & $23.5 \pm 2.25$ & 2 \\
\hline
\end{tabular}




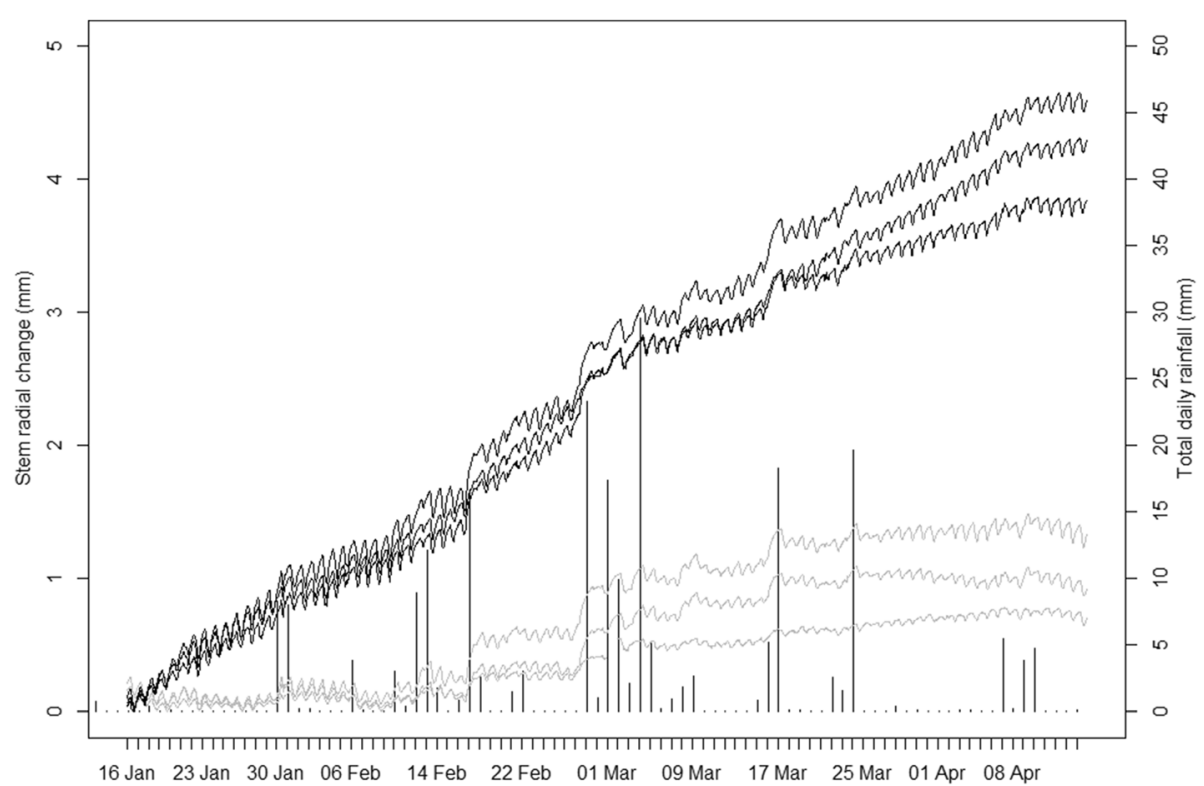

Fig. 5 Hourly changes in stem size (from a zeroed start point on January 15th, 2012) in the thinned (black) and unthinned (grey) trees at Flynn until the end of April 2012. Total daily rainfall at the site is shown by black bars. Note the marked responses to rainfall on 28th February and 15th March at both sites. Note also that in unthinned plots there was no net increment until the rainfall of 14th February, while the thinned plots growth was continuous over the same period
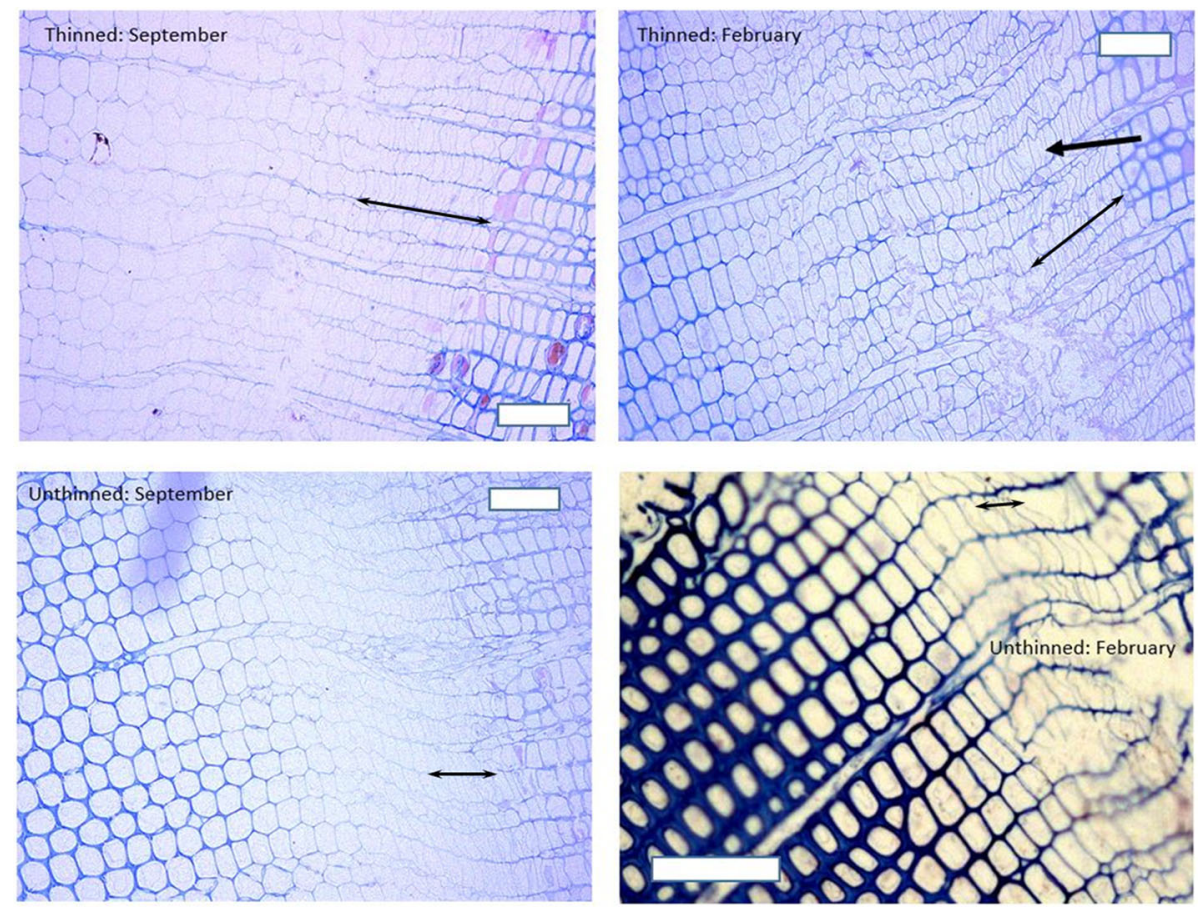

Fig. 6 Examples of the cambium and zone of enlarging xylem from thinned and unthinned plots in September 2011 and February 2012. The phloem is on the right side of each image. The image bars indicate $100 \mu \mathrm{m}$. Double sided arrows show the estimated widths of the cambial zone in which cells are still likely to be meristematic. Note the wide cambial zone and evidence of cambial activity evident in a typical tree in the thinned treatment (one-sided arrow indicates a newly formed cell wall/plate) in February which was not the case in any of the trees in the unthinned treatment at the site 
Table 7 Numbers of cambial initials and enlarging cells counted from samples from trees at the Flynn site in September, November and December 2011 and February 2012

\begin{tabular}{lllll}
\hline Treatment & Date of sampling & Cambial zone cells (\#) & Enlarging zone cells (\#) & CZ cells/EZ cells \\
\hline Thinned & $2011 / 09 / 20$ & $16.3 \pm 2.9$ & $14.3 \pm 1.9$ & $1.1 \pm 0.05$ \\
& $2011 / 11 / 03$ & $10.0 \pm 1.0$ & $10.0 \pm 2.0$ & $1 \pm 0.10$ \\
& $2011 / 12 / 15$ & $18.5 \pm 0.5$ & $15.5 \pm 0.5$ & $1.2 \pm 0.07$ \\
& $2012 / 02 / 10$ & $14.3 \pm 1.3$ & $14.3 \pm 1.3$ & $1 \pm 0.01$ \\
Unthinned & $2011 / 09 / 20$ & $8.0 \pm 0.1$ & $6.0 \pm 0.0$ & $1.3 \pm 0.01$ \\
& $2011 / 11 / 03$ & $7.0 \pm 1.5$ & $5.3 \pm 1.3$ & $1.3 \pm 0.08$ \\
& $2011 / 12 / 15$ & $5.0 \pm 1.0$ & $5.7 \pm 1.3$ & $1.4 \pm 0.33$ \\
& $2012 / 02 / 10$ & $5.5 \pm 0.5$ & $4.0 \pm 1.0$ & $1.4 \pm 0.23$ \\
\hline
\end{tabular}

stems $\cdot \mathrm{ha}^{-1}$ ) were still significantly different (smaller) in size from trees which had either been planted at 1111 stems.ha ${ }^{-1}$ and thinned to 556 stems.ha ${ }^{-1}$, or those which had always been at 556 stems.ha ${ }^{-1}$. At Flynn, the advantage from thinning and subsequent marked reductions in stand density was maintained by trees in the thinned plots during the period of our study, with the thinned plots exhibiting markedly higher growth rates. At Mt. Gambier, however, this was not the case, and despite the previously unthinned (but more sparsely planted) trees being larger than trees in the other two treatments (i.e. having grown faster up until the time of our study), they were the slower growing trees while monitored during our study. Other research has shown, however (e.g. Valinger et al. 2000 in scots pine), that increased rates of growth in thinned stands could still be detected as long as 12 years after thinning, and differences in growth have been observed as long as 6 years following certain types of thinning in P. radiata (Cremer and Meredith 1976). It is possible, therefore, that trees in the thinned plots at Mt. Gambier were still exhibiting something of a "thinning response" (Snowdon 2002; Burkhart and Tomé 2012) during our study, even years after thinning occurred. We speculate that potentially trees in these previously thinned plots were still able to further explore the site in a way those in the never--thinned plots could not do.

Unfortunately, however, our data did not allow us to determine in more detail what was behind these treatment-level effects, e.g. differences in canopy development. However, we were able to explore concomitant short-term dynamics. The use of dendrometers proved to be a useful approach to tackling this question. While in some studies, difficulties in assessing onset of growth due to ambiguity resulting from effects of non-growthrelated hydration events (Korpela et al. 2010), a simple method of using a proportional point to ascertain timing of growth onset and cessation worked well in our study. More complex methods can be used (Korpela et al. 2010; van der Maaten 2013), but this was not deemed necessary here where growth increments were large, relative to the "noise" often present in dendrometer data, and generally continuous.

Effects of thinning and stand density on growth dynamics We postulated that the differences in cumulative growth seen between trees in the different thinning treatments could, in principle, be explained by differences in one or more of three main dynamics (Linderholm 2006). We conjectured that some combination of all three of these possibilities led to the observed differences between the two treatments at Flynn, and between the two thinned vs unthinned (but now at constant SPH) treatments at Mt. Gambier.

Some studies have found that larger, dominant trees retained a competitive advantage by starting to grow earlier than smaller and suppressed trees (Rathgeber et al. 2011; Vieira et al. 2015). Other studies (e.g. van der Maaten 2013 in European beech) have observed that thinning can stimulate earlier onset and a longer season duration. In our study, while we did not find evidence that the timing of onset of seasonal growth was a clear factor in determining differences in overall growth between thinned/unthinned plots, it was clear that thinning affected the timing of the cessation of growth in the major growing season: growth in trees in thinned plots ceased later in the season at both sites. It is particularly notable that even in the case of Mt. Gambier, where all stands were (for our study) at the same stand density, those trees which had previously been thinned ceased growing later in the season than those never thinned.

In addition, we found at both the Mt. Gambier and Flynn sites that the slower growing, never-thinned treatments had fewer days of detectable increment (within the season) than in previously thinned plots. Interpreting the occurrence of a detectable "over-bark" increment as measured by the dendrometers is, of course, complicated by water movement into expansible tissues, and other effects, and is not purely a function of the occurrence of cell production and irreversible expansion (Mäkinen et 
al. 2003; Zweifel et al. 2006; Drew et al. 2014) and ultimately "growth". However, it is almost certain that cambial activity would be substantially reduced, if not stopped, when no growth was detectable (Abe et al. 2003; Gruber et al. 2010). Certainly, trees in unthinned plots maintained an overall smaller cambial zone than thinned plots. It is interesting, however, and consistent with previous findings in $P$. radiata by researchers like Skene (1969), that the sizes of these zones remained fairly constant throughout the season (although possibly a small decline was evident very late in the season in the unthinned plots). Potentially, the relatively more erratic growth during the season in the unthinned plots may have been more a function of variable meristematic activity in a constant-sized cambial zone than of constant expansion/reduction in the size of the meristematic population. The higher ratio between cambial and enlarging cells suggests that the unthinned plots also had a lower duration of enlargement than the thinned plots (cf. Drew and Pammenter 2007).

On days when increment did occur, rates did not differ at all at Flynn, and at Mt. Gambier, by a far smaller margin, between the thinned and unthinned treatments. That is, growth rates were relatively high, temporarily, on "growth days" in the unthinned treatments, but not maintained. These temporary, pulse-like (Zeppel et al. 2008; Drew et al. 2009; De Swaef et al. 2015) responses will be a combination of both a short-term hydration of flexible tissues, and a substantial, but temporary, enhancement of rates of cell division and irreversible tracheid radial/longitudinal expansion (Downes et al. 2009; Zweifel et al. 2014).

It is reasonable to conclude, from our data, that during and at the end of the season limitations from lack of resources became acute in cases where trees were competing more heavily. By contrast, the onset of growth was not affected by these resource limitations.

\section{Seasonal conditions and the timing of growth}

Early season temperatures have been shown by a number of authors, often in boreal conifers, to have an important effect in controlling the onset and ending of xylogenesis (Kramer et al. 2000; Rossi and Deslauriers 2007; Rossi et al. 2008; Moser et al. 2009; Bryukhanova and Fonti 2012). In our study, however, the onset of seasonal growth was not apparently affected by whether or not winter conditions were warmer or colder between years. In fact, it is notable that in onset of growth occurred right in the middle of winter, when temperatures were at (or close to) their lowest values, and day length was also not much longer than the winter solstice (about 21 June). Similar early (winter) onset of growth has been seen in radiata pine in places like New Zealand (Tennent 1986) where the conditions on the North Island are comparable to what we had in our study. These findings suggest very strongly that temperature in the very moderate and mild conditions at which the trees were growing in our study, in southern mainland Australia, is of no consequence as a determinant of the timing of growth in Pinus radiata. Certainly, this has been found in Australian $P$. radiata, in terms of general physiological activity, including bud elongation and internode extension in $P$. radiata, which occurred throughout the year (Cremer 1973). Similarly, Barnett (1971) found that $P$. radiata the cambium never became truly dormant. These attributes of $P$. radiata, growing in this relatively mild environment, may also be a reason why growth was not maximized later in the season. We did not find, as has been found in studies on northern conifers in colder regions (e.g. Rossi et al. 2006b) that maximum growth rates occurred around the time of the longest days. Rather, it would seem that growth rates are as high as ever, if not maximized (this was not always distinct), soon after growth onset, or (at the latest) towards the end of the Spring flush.

By contrast, it was evident that the cessation of growth did differ between years. Growth ceased, at both sites, earlier in the drier (based on both rainfall and evaporation) years. This was not surprising, as other studies have shown that trees growing under drier conditions have been shown to cease growth earlier than trees in less xeric conditions (Gruber et al. 2010). Through the effect of water availability on tree water relations, these conditions can be expected to cause a reduction in cambial activity, tracheid expansion and general phenology and metabolism (Hinckley et al. 1979; Kramer et al. 2000; Drew et al. 2014).

Other phenological changes, in concert with these differing conditions will likely also play a role. Timing of flowering has been shown to play in a role in P. radiata, for example (Fernández and Cornejo 2016) and cessation of growth may be in large part due to phenomena at the tree-level which are themselves linked to the drier conditions. Some work suggests that bud activity and shoot extension in $P$. radiata is also reduced or temporarily ceases in late summer/early autumn, probably also for drought-related reasons (Bollmann and Sweet 1979). Overall, however, our data would suggest that growing season in $P$. radiata growing under conditions such as in our study, is more determined by conditions in the late summer months, not temperature related per sé (except insofar as high temperatures may lead to drought-stressed conditions).

\section{Data supporting fine-scale models of growth}

Detailed fine-scale data on growth dynamics provide an opportunity to validate and calibrate models on new metrics, in addition to only yield. That is, process-based or hybrid models should predict not only that overall 
growth rates are higher in thinned stands, but also the changes in duration of season and number of growth days. This is particularly the case with fine temporal scale models such as CABALA (Battaglia et al. 2015) which are applied in predicting $P$. radiata growth and yield in Australia and internationally (Drew and Downes 2015; Drew et al. 2017). It makes particular sense to link fine-scale dynamics in stem radial growth and wood formation to morphological and phenological variables, in appropriately developed functional-structural models, such as the framework proposed by Fernández et al. (2011).

\section{Conclusions}

While our study is limited, it was clear at both sites that early season (i.e. late winter/early spring) temperature had no clear effect on the timing of the season's growth. By contrast, however, conditions late in summer, particularly drought, have an important effect on the timing of cessation of growth. Drier conditions led to an earlier cessation. This was mirrored in the effect of thinning, where the timing of cessation of growth was extended by undertaking any kind of thinning as compared to no thinning, even at relatively low stand densities.

\section{Abbreviations}

AC LVDT: Alternating current linear variable displacement transducer; DBH: Diameter at breast height; ForestrySA: Forestry South Australia; HVP: Hancocks Victorian plantations; SD: Stand density; Tukey's HSD: Tukey's honest significant difference; VPD: Vapour pressure deficit; WMD: Weighted mean wood density

\section{Acknowledgements}

The authors gratefully acknowledge the invaluable contributions of Steven Elms and Ross Gillies at Hancock Victoria Plantations (HVP) and Don Mc Guire, Jim O'Hehir and the technical support team at (then) Forestry South Australia (FSA)

\section{Funding}

The work was funded in large part by a grant (PNC 196-1011) from Forest and Wood Products Australia (FWPA) and funding and in-kind support from HVP, FSA and CSIRO.

\section{Availability of data and materials}

Data will not be shared until work currently underway on the current development of a commercial growth model has been completed.

\section{Authors' contributions}

DMD and GMD both contributed equally to the initial design of the research and to the installation of the equipment in the field, as well as to data management (DMD $=50 \% ; \mathrm{GMD} 50 \%)$. DMD led the analysis for this manuscript ( $\mathrm{DMD}=60 \% ; \mathrm{GMD}=40 \%$ ) and $\mathrm{DMD}$ led the writing of the manuscript, although GMD made significant interpretive, editorial and linguistic contributions throughout the process ( $D M D=60 \% ; G M D=40 \%$ ). Both authors read and approved the final manuscript.

Ethics approval and consent to participate Not applicable.

\section{Consent for publication}

Not applicable.

\section{Competing interests}

The authors declare that they have no competing interests.

\section{Author details}

${ }^{1}$ Department of Forest and Wood Science, Stellenbosch University, Private Bag X1, Matieland 7800, South Africa. ${ }^{2}$ Forest Quality Pty Ltd., PO Box 293, Huonville, TAS, Australia.

Received: 30 April 2018 Accepted: 3 September 2018

Published online: 09 October 2018

\section{References}

Abe H, Nakai T, Utsumi Y, Kagawa A (2003) Temporal water deficit and wood formation in Cryptomeria japonica. Tree Physiol 23:859-863

Barnett JR (1971) Winter activity in the cambium of Pinus radiata. New Zeal J For Sci 1:208-222

Battaglia M, Bruce J, Latham R, O'Grady A, Greenwood A (2015) Forest ecology and management process-based size-class distribution model of trees within forest plantations : a hierarchical modeling approach. For Ecol Manag 344: 63-72. https://doi.org/10.1016/j.foreco.2015.02.015

Beesley C, Frost A, Zajaczkowski I (2009) A comparison of the BAWAP and SILO spatially interpolated daily rainfall datasets. In: 18th world IMACS/MODSIM congress, Cairns, Australia 2009, pp 13-17

Bollmann MP, Sweet GB (1979) Bud morphogenesis of Pinus radiata in New Zealand 2: the seasonal shoot growth pattern of seven clones at four sites. New Zeal J For Sci 9:153-165

Bosio F, Rossi S, Marcati CR (2016) Periodicity and environmental drivers of apical and lateral growth in a Cerrado woody species. Trees 30:1495-1505

Brinkmann N, Eugster W, Zweifel R, Nina B, Ansgar K (2016) Temperate tree species show identical response in tree water de fi cit but di ff erent sensitivities in sap fl ow to summer soil drying. Tree Physiol:1-12. https://doi. org/10.1093/treephys/tpw062

Bryukhanova M, Fonti P (2012) Xylem plasticity allows rapid hydraulic adjustment to annual climatic variability. Trees-Structure Funct. https://doi.org/10.1007/ S00468-012-0802-8

Burkhart HE, Tomé M (2012) Modeling forest trees and stands. McGraw-Hill, New York

Cremer KW (1973) Seasonal patterns of shoot development in Pinus radiata near Canberra. Aust For Res 6:31-53

Cremer KW, Meredith EM (1976) Growth of radiata pine after row thinning compared with selective thinning. Aust For 39:193-200

De Swaef T, De Schepper V, Vandegehuchte MW, Steppe K (2015) Stem diameter variations as a versatile research tool in ecophysiology. Tree Physiol 35:10471061

Deslauriers A, Rossi S, Anfodillo T (2007) Dendrometer and intra-annual tree growth: what kind of information can be inferred? Dendrochronologia 25:113-124

Downes G, Beadle C, Worledge D (1999) Daily stem growth patterns in irrigated Eucalyptus globulus and E. nitens in relation to climate. Trees-Structure Funct 14:102-111

Downes GM, Drew D, Battaglia M, Schulze D (2009) Measuring and modelling stem growth and wood formation: an overview. Dendrochronologia 27:147-157

Downes GM, Drew DM (2008) Climate and growth influences on wood formation and utilisation. South For a J For Sci 70:155-167

Downham R, Gavran M (2017) Australian plantation statistics 2017 update. Aust Gov Dep Agric Water Resour Canberra, Aust 12

Drew DM, Bruce J, Downes GM (2017) Future wood properties in Australian forests: effects of temperature, rainfall and elevated $\mathrm{CO}_{2}$. Aust For:1-13. https://doi.org/10.1080/00049158.2017.1362937

Drew DM, Downes G (2015) A model of stem growth and wood formation in Pinus radiata. Trees 29:1395-1413. https://doi.org/10.1007/s00468-015-1216-1

Drew DM, Downes GM, Evans R (2011) Short-term growth responses and associated wood density fluctuations in variously irrigated Eucalyptus globulus. Trees 25:153-161

Drew DM, Downes GM, Grzeskowiak V, Naidoo T (2009) Differences in daily stem size variation and growth in two hybrid eucalypt clones. Trees 23:585

Drew DM, Grady APO, Downes GM, Worledge D (2008) Daily patterns of stem size variation in irrigated and unirrigated Eucalyptus globulus. Tree Physiol 28(10):1573-1581

Drew DM, Pammenter NW (2007) Developmental rates and morphological properties of fibres in two eucalypt clones at sites differing in water availability. South Hemisph For J 69:71-79

Drew DM, Richards AE, Cook GD, Downes GM, Gill W, Baker PJ (2014) The number of days on which increment occurs is the primary determinant of annual ring width in Callitris intratropica. Trees 28:31-40 
Fernández MP, Cornejo B (2016) Is the first flowering event and corresponding maturity phase in trees related to radial wood density changes? Trees 30: 859-870

Fernández MP, Norero A, Vera JR, Pérez E (2011) A functional--structural model for radiata pine (Pinus radiata) focusing on tree architecture and wood quality. Ann Bot 108:1155-1178

Gruber A, Strobl S, Veit B, Oberhuber W (2010) Impact of drought on the temporal dynamics of wood formation in Pinus sylvestris. Tree Physiol 30:490-501

Hinckley TM, Dougherty PM, Lassoie JP, Roberts JE, Teskey RO (1979) A severe drought: impact on tree growth, phenology, net photosynthetic rate and water relations. Am Midl Nat:307-316

Ivković M, Hamann A, Gapare WJ, Jovanovic T, Yanchuk A (2016) A framework for testing radiata pine under projected climate change in Australia and New Zealand. New For 47:209-222

Jeffrey SJ, Carter JO, Moodie KB, Beswick AR (2001) Using spatial interpolation to construct a comprehensive archive of Australian climate data. Environ Model Softw 16:309-330

Korpela M, Mäkinen H, Nöjd P, Hollmen J, Sulkava M (2010) Automatic detection of onset and cessation of tree stem radius increase using dendrometer data. Neurocomputing 73:2039-2046

Kramer K, Leinonen I, Loustau D (2000) The importance of phenology for the evaluation of impact of climate change on growth of boreal, temperate and Mediterranean forests ecosystems: an overview. Int J Biometeorol 44:67-75

Lavery PB, Mead DJ (1998) Pinus radiata: a narrow endemic from North America takes on the world. In: Richardson, D.M. (Ed.) Ecology and Biogeography of Pinus. Cambridge University Press, Cambridge, pp. 432-449.

Leech J (2014) Rotation length and discount rates. Aust For 77:114-122

Linderholm HW (2006) Growing season changes in the last century. Agric For Meteorol 137:1-14

Mäkinen H, Nöjd P, Saranpää P (2003) Seasonal changes in stem radius and production of new tracheids in Norway spruce. Tree Physiol 23:959-968

Moser L, Fonti P, Büntgen U, Esper J, Luterbacher J, Franzen J, Frank D (2009) Timing and duration of European larch growing season along altitudinal gradients in the Swiss alps. Tree Physiol 30:225-233

Olivar J, Bogino S, Rathgeber C, Bonnesoeur V, Bravo F (2014) Thinning has a positive effect on growth dynamics and growth--climate relationships in Aleppo pine (Pinus halepensis) trees of different crown classes. Ann For Sci 71:395-404

R Core Team (2016) R: a language and environment for statistical computing. R Foundation for Statistical Computing

Rathgeber CBK, Rossi S, Bontemps J-D (2011) Cambial activity related to tree size in a mature silver-fir plantation. Ann Bot 108:429-438

Rossi S, Anfodillo T, Menardi R (2006a) Trephor: a new tool for sampling microcores from tree stems. IAWA J 27:89-97

Rossi S, Deslauriers A (2007) Intra-annual time scales in tree rings. Dendrochronologia 25:75-77

Rossi S, Deslauriers A, Anfodillo T, Morin H, Saracino A, Motta R, Borghetti M (2006b) Conifers in cold environments synchronize maximum growth rate of tree-ring formation with day length. New Phytol 170:301-310

Rossi S, Deslauriers A, Griçar J, Seo JW, Rathgeber CBK, Anfodillo T, Morin H, Levanic T, Oven P, Jalkanen R (2008) Critical temperatures for xylogenesis in conifers of cold climates. Glob Ecol Biogeogr 17:696-707

Skene DS (1969) The period of time taken by cambial derivatives to grow and differentiate into tracheids in Pinus radiata. D Don Ann Bot 33:253-262

Snowdon P (2002) Modeling type 1 and type 2 growth responses in plantations after application of fertilizer or other silvicultural treatments. For Ecol Manag 163:229-244

Steppe K, Sterck F, Deslauriers A (2015) Diel growth dynamics in tree stems: linking anatomy and ecophysiology. Trends Plant Sci 20:335-343. https://doi. org/10.1016/j.tplants.2015.03.015

Tennent RB (1986) Intra-annual growth of young Pinus radiata in New Zealand. New Zeal J For Sci 16:166-175

Valinger E, Elfving B, Mörling T (2000) Twelve-year growth response of scots pine to thinning and nitrogen fertilisation. For Ecol Manag 134:45-53

van der Maaten E (2013) Thinning prolongs growth duration of European beech (Fagus sylvatica L.) across a valley in southwestern Germany. For Ecol Manag 306:135-141

Vieira J, Campelo F, Rossi S, Carvalho A, Freitas H, Nabais C (2015) Adjustment capacity of maritime pine cambial activity in drought-prone environments. PLOS One 10:e0126223

Worrall J (1966) A method of correcting dendrometer measures of tree diameter for variations induced by moisture stress change. For Sci 12:427-429
Zeppel M, Macinnis-Ng CMO, Ford CR, Eamus D (2008) The response of sap flow to pulses of rain in a temperate Australian woodland. Plant Soil 305:121-130

Zweifel R, Drew DM, Schweingruber F, Downes GM (2014) Xylem as the main origin of stem radius changes in Eucalyptus. Funct Plant Biol 41:520-534

Zweifel R, Zimmermann L, Zeugin F, Newbery DM (2006) Intra-annual radial growth and water relations of trees: implications towards a growth mechanism. J Exp Bot 57:1445-1459

\section{Submit your manuscript to a SpringerOpen ${ }^{\circ}$ journal and benefit from:}

- Convenient online submission

- Rigorous peer review

- Open access: articles freely available online

- High visibility within the field

- Retaining the copyright to your article

Submit your next manuscript at $>$ springeropen.com 